\title{
Effectiveness of skin protectors and calendula officinalis for prevention and treatment of radiodermatitis: an integrative review
}

\author{
Efetividade de protetores cutâneos e calendula officinalis para prevenção e tratamento \\ de radiodermatites: revisão integrativa \\ Eficacia de los protectores de la piel y Calendula officinalis para la prevención y tratamiento \\ de la radiodermatitis: revisión integrativa
}

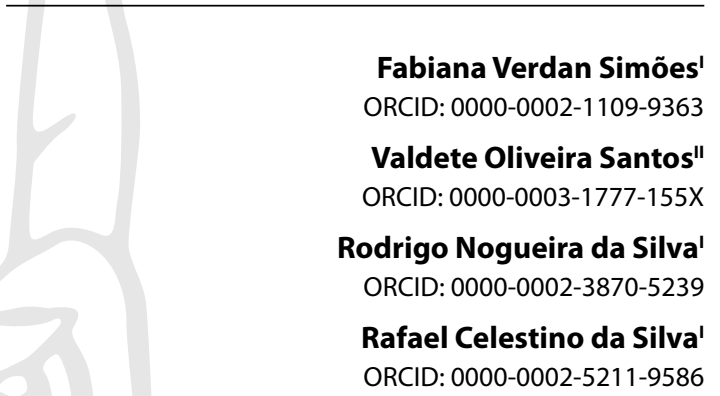

'Universidade Federal do Rio de Janeiro. Rio de Janeiro, Rio de Janeiro, Brazil.

"Instituto Nacional de Câncer José Alencar Gomes da Silva. Rio de Janeiro, Rio de Janeiro, Brazil.

How to cite this article: Simões FV, Santos VO, Silva RN, Silva RC. Effectiveness of skin protectors and calendula officinalis for prevention and treatment of radiodermatitis: an integrative review.

Rev Bras Enferm. 2020;73(Suppl 5):e20190815. doi: http://dx.doi.org/10.1590/0034-7167-2019-0815

Corresponding author:

Rafael Celestino da Silva

Email: rafaenfer@yahoo.com.br

EDITOR IN CHIEF: Dulce Barbosa ASSOCIATE EDITOR: Ana Fátima Fernande

Submission: 02-04-2020

Approval: 07-18-2020

\begin{abstract}
Objective: to analyze the effectiveness of skin protectors spray and Calendula officinalis for prevention and treatment of radiodermatitis. Method: an integrative review conducted at CINAHL, Cochrane Library, Embase, MEDLINE/PubMed, IBECS, LILACS, and Web of Science. The final sample consisted of five studies, four clinical studies and one preclinical. Critical appreciation and narrative synthesis of the findings were carried out. Results: the Cavilon ${ }^{\text {TM }}$ skin protector was more effective than Sorbolene (cream with $10 \%$ glycerin) and less effective than Mometasone Furoate cream. Calendula officinalis was more effective than Trolamine and essential fatty acids and less effective than Ching Wan Hung for prevention and treatment of radiodermatitis. Conclusion: data confirm the potential of Calendula officinalis for prevention and treatment of radiodermatitis and point to promising results regarding skin protector spray use; however, there is a need for further testing as to the effectiveness of such products. Descriptors: Neoplasms; Radiodermatitis; Calendula; Oncology Nursing; Review.
\end{abstract}

\section{RESUMO}

Objetivo: analisar a efetividade de protetores cutâneos spray e da Calendula officinalis para a prevenção e tratamento de radiodermatites. Método: revisão integrativa, nas bases de dados CINAHL, Cochrane Library, Embase, MEDLINE/PubMed, IBECS, LILACS e Web of Science. A amostra final foi composta por cinco estudos, quatro pesquisas clínicas e uma pré-clínica. Foram realizadas a apreciação crítica e síntese narrativa dos achados dos estudos. Resultados: o protetor cutâneo Cavilon ${ }^{T M}$ foi mais efetivo que Sorbolene (creme com $10 \%$ de glicerina) e menos efetivo que creme de Furoato de Mometasona. Calendula officinalis foi mais efetivo que Trolamina e ácidos graxos essenciais e menos efetivo que Ching Wan Hung ${ }^{\circ}$ para a prevenção e tratamento de radiodermatite. Conclusão: os dados confirmam o potencial da Calendula officinalis na prevenção e tratamento da radiodermatite e apontam resultados promissores quanto ao uso dos protetores cutâneos spray, entretanto há necessidade de novas testagens quanto à efetividade de tais produtos.

Descritores: Neoplasias; Radiodermatite; Calendula; Enfermagem Oncológica; Revisão.

\section{RESUMEN}

Objetivo: analizar la eficacia de los protectores cutáneos spray y Calendula officinalis para la prevención y el tratamiento de la radiodermatitis. Método: revisión integradora, en las bases de datos CINAHL, Cochrane Library, Embase, MEDLINE/PubMed, IBECS, LILACS y Web of Science. La muestra final consistió en cinco estudios, cuatro estudios clínicos y uno preclínico. Se llevó a cabo una apreciación crítica y síntesis narrativa de los hallazgos del estudio. Resultados: el protector de piel Cavilon ${ }^{T m}$ fue más efectivo que $S$ butterflyene (crema con $10 \%$ de glicerina) y menos efectivo que la crema de Furoato de Mometasona. Calendula officinalis fue más eficaz que la trolamina y los ácidos grasos esenciales y menos eficaz que Ching Wan Hung para la prevención y el tratamiento de la radiodermatitis. Conclusión: los datos confirman el potencial de Calendula officinalis en la prevención y el tratamiento de la radiodermatitis y apuntan a resultados prometedores en cuanto al uso de protectores cutáneos spray, sin embargo, existe la necesidad de nuevas pruebas sobre la efectividad de dichos productos.

Descriptores: Neoplasias; Radiodermatitis; Calendula; Enfermería Oncológica; Revisión. 


\section{INTRODUCTION}

Cancer is a health condition in which cells in a certain part of the body, due to some mutation in the genome, grow and reproduce uncontrollably. More than 18 million new cancer cases were registered in the world in 2018 alone, in addition to more than 9.5 million cancer deaths in the same period ${ }^{(1)}$. Estimates show that, in Brazil alone, in 2018, there were more than 630 thousand new cases of malignant neoplasms ${ }^{(2)}$.

Among the ways to treat cancer, such as surgery, chemotherapy, or bone marrow transplantation, radiotherapy stands out in this study. Radiotherapy is a safe and highly effective treatment against cancer, either for healing or for palliation, which works by emitting ionizing radiation in a region of the body, in order to destroy and prevent tumor cells from growing ${ }^{(3)}$. About half of cancer patients receive radiation therapy, although it is not restricted to the treatment of this type of disease ${ }^{(4)}$. Despite being a very precise technique, normal tissues that are exposed to radiation can suffer toxic effects. Such effects can be short term, during treatment or up to three months after it ends, or long term, after three months of ending treatment ${ }^{(3)}$.

Radiodermatitis is one of those toxic effects of radiotherapy that can occur in the short term. Ninety-five percent of patients treated with radiotherapy develop moderate or severe skin reactions $s^{(5)}$. lonizing radiation acts on the epidermis attacking its self-regenerating properties, offering no time for cells to repair tissue or DNA damage when exposure to ionizing radiation is repeated, which leads to radiodermatitis ${ }^{(3)}$.

Clinical radiodermatitis ranges from short-term effects, such as erythema, dry flaking and wet flaking, to long-term effects, such as changes in skin pigmentation, telangiectasias, alopecia, atrophy, and ulcerations ${ }^{(3)}$. The more severe the effects of radiodermatitis, the greater the loss of general quality of life and in the domains symptoms and feelings, daily activities, leisure, work, and school(6).

In some topographies, there is a higher prevalence of radiodermatitis combined with more severe degrees of toxicity (starting from grade 3 - confluent moist flaking), as is the case of patients who treat anal, head, neck, breast, and gynecological cancer ${ }^{(7-8)}$. Evidence is seen in a study in which the authors analyzed 152 patients with anal cancer, who underwent chemo and radiotherapy with modulated intensity (IMRT), which identified that $20 \%$ of patients had severe skin reactions (grade $>=3$ ) and $11 \%$ in the gastrointestinal system. The authors considered that this percentage of reactions may be higher in conventional techniques, considering that IMRT is better in reducing treatment toxicity ${ }^{(7)}$.

Toxicity management is performed by nurses in the nursing consultation and by radio-oncologist doctors. In the observation of more severe degrees of radiodermatitis, patients are referred for medical review to assess the temporary interruption of radiotherapy, which can cause failure in local control of the disease and compromise their safety ${ }^{(9)}$.

Studies report that unplanned interruptions during radiotherapy are related to the possibility of negatively influencing the prognosis, with reduced rates of cure in several irradiated regions, such as head and neck, cervix, breast, lung, and anus ${ }^{(10-11)}$.

The standard treatment for radiodermatitis involves using aqueous creams with corticosteroids, such as creams with Mometasone
Furoate, or with herbal medicines, such as Calendula officinalis, in addition to $1 \%$ Silver Sulfadiazine use. Calendula officinalis is a plant with therapeutic purposes recognized by the European Medicines Agency since 2008, having anti-inflammatory, antispasmodic, healing, antioxidant, antibacterial, antifungal, immunostimulating properties, among others, and has also been applied and recommended for prevention and treatment of radiodermatitis ${ }^{(12)}$. However, this herbal medicine still has its effectiveness for prevention and treatment of radiodermatitis classified as "probable" by the Oncology Nursing Society, a category in which more empirical studies and synthesis of evidence on its effectiveness are needed ${ }^{(13)}$.

New alternatives for prevention and treatment of radiodermatitis have emerged involving skin protectors, such as Mepitel and $3 \mathrm{M}^{\mathrm{TM}}$ Cavilon $^{\mathrm{TM}}$ No Sting Barrier Film ${ }^{(13-14)}$. Skin protectors for the treatment of radiodermatitis are non-pharmacological products that can be presented in the form of spray, cream, or silicone film, being applied over a specific region of the skin, forming a protective film against friction and contamination ${ }^{(14-15)}$. Its use for dermatitis associated with incontinence is already known. The Oncology Nursing Society points out skin protectors as products whose effectiveness for prevention and treatment of radiodermatitis is not yet established ${ }^{(13)}$.

In the Assistance Protocol for Radiodermatitis of a referral center for cancer care, developed based on the Oncology Nursing Society, in patients who are starting treatment and who have healthy skin, the first choice for prevention is a moisturizer that has Calendula Officinalis in its composition, and 1\% Silver Sulfadiazine for treatment, when wet flaking is observed. Products such as no sting skin protectors, hydrogel, hydrocolloids and essential fatty acids are second or third choice, used only in cases of allergy or resistance to $1 \%$ Silver Sulfadiazine.

For patients who have radiodermatitis irradiated to the pelvis, whose skin is intact, but complain of diarrhea or intermittent anal or vaginal secretion, it is recommended to use a skin protector spray, replacing the marigold-based moisturizer. Based on the researcher's expertise, analysis of the literature and clinical results obtained using skin protectors in the referred reference center, it was conjectured about the clinical benefits of such a product if it were indicated in the institutional protocol since the beginning of treatment. Bearing that in mind, the research question that guided the study was: what is the effectiveness of skin protectors spray and Calendula officinalis for prevention and treatment of radiodermatitis?

Radiodermatitis is one of the most frequent treatment toxicities, whose severity can cause treatment interruption, pain and worse quality of life ${ }^{(16)}$. In light of this, studies that aim to generate evidence about products to prevent and treat radiodermatitis contribute to updating the nurse's practice. They aim at the implementation of new care technologies and a more adequate care to the needs of oncology patients undergoing radiotherapy, which has scientific and social relevance.

\section{OBJECTIVE}

This study aims to analyze the effectiveness of skin protectors spray and Calendula officinalis for prevention and treatment of radiodermatitis. 


\section{METHOD}

\section{Type of study}

This is an Integrative Review, an evidence synthesis method that serves as a tool for Evidence-Based Practice and facilitates the process of incorporating scientific evidence into clinical practice ${ }^{(17)}$. Six steps of the method were applied: (1) theme identification and hypothesis or research question selection; (2) establishment of criteria for inclusion and exclusion of studies and search in the literature; (3) definition of the information to be extracted from selected studies and study categorization; (4) study assessment; (5) interpretation of results; (6) review presentation ${ }^{(15)}$. PRISMA guidelines support was used to develop this study.

\section{Study setting}

Literature searches were carried out in November 2018 and reviewed in January and February 2019 in the following libraries, databases and search engines: CINAHL via EBSCOhost, Cochrane Library, Embase, MEDLINE/PubMed, IBECS, LILACS, and Web of Science (All Databases). The research question was defined according to the Client Oriented model, Practical Evidence Search $(C O P E S)^{(18)}$, which guides its structure in problem, intervention, alternative intervention and outcome, allowing also to select researches that assess the effectiveness of an intervention by turn. Thus, the question was: what is the effectiveness of skin protectors spray and Calendula officinalis for reducing or delaying the symptoms of radiodermatitis? The problem was radiodermatitis, the intervention was skin protectors, the alternative intervention was Calendula officinalis and the outcome was prevention, understood as a decrease or delay in the symptoms of radiodermatitis.

\section{Data source}

The data source was scientific articles available in the chosen databases. To select such documents, the following inclusion criteria were defined: primary studies; in English, Portuguese, or Spanish; that covered significant elements of the research question; referred to using skin protector spray or marigold as an active principle or associated with other active compounds. There was no time frame for the search. The exclusion criterion was using products to treat chronic radiodermatitis. Study selection was carried out by two reviewers with experience in the field of radiotherapy nursing, independently, with no disagreements regarding the final sample.

Search terms, including descriptors and keywords, corresponding to each significant element of the research question, were recruited and organized using Boolean operators and search codes according to the information sources consulted. Chart 1 presents all terms used for each significant element of the research question.

In compliance with PRISMA guidelines, used to support the presentation of this review, which makes it possible to present the complete search strategy of just one of the databases consulted, the search strategy used in the Embase database is presented as an example, considering the restriction on the number of pages in this article, according to Chart 2.
Chart 1 - Terms used in search strategies

\begin{tabular}{|l|l|l|}
\hline Problem/Outcome & Intervention & Alternative Intervention \\
\hline Radiation injuries & Barrier film & Calendula officinalis \\
Radiodermatitis & Skin film & \\
Radiation-induced & Barrier film & \\
skin toxicity & Protective film & \\
& Skin protector & \\
\hline
\end{tabular}

Chart 2 - Embase search strategy

\begin{tabular}{|l|l|}
\hline Database & Search strategy \\
\hline Embase & $\begin{array}{l}\text { ('radiation dermatitis'/of OR'radiation injury'/ } \\
\text { of OR'radiation dermatitis':ti,ab,kw OR } \\
\text { 'radiodermatitis':ti,ab,kw OR'radioepithelitis':ti,ab,kw } \\
\text { OR'radiation injuries':ti,ab,kw OR'radiation } \\
\text { injury':ti,ab,kw OR'radiation-induced } \\
\text { dermatitis':ti,ab,kw OR'radiation-induced skin } \\
\text { toxicity':ti,ab,kw) AND ('barrier film':ti,ab,kw OR'barrier } \\
\text { films':ti,ab,kw OR nsbf OR'film barrier':ti,ab,kw OR } \\
\text { 'film barriers':ti,ab,kw OR'barrier product':ti,ab,kw } \\
\text { OR'barrier products':ti,ab,kw OR'moisture } \\
\text { barrier':ti,ab,kw OR'moisture barriers':ti,ab,kw } \\
\text { OR'liquid-film':ti,ab,kw OR'liquid-films':ti,ab,kw } \\
\text { OR'cutaneous protector':ti,ab,kw OR'cutaneous } \\
\text { protectors':ti,ab,kw OR'skin protector':ti,ab,kw OR'skin } \\
\text { protectors':ti,ab,kw OR'skin protectant':ti,ab,kw OR } \\
\text { 'skin protectants':ti,ab,kw OR'skin film':ti,ab,kw OR'skin } \\
\text { films':ti,ab,kw OR spray*:ti,ab,kw OR'calendula'/exp OR } \\
\text { 'calendula extract'/de OR'calendula officinalis extract'/ } \\
\text { de OR 'calendula':ti,ab,kw) AND ([English]/lim OR } \\
\text { [Portuguese]/lim OR [Spanish]/lim) AND [Embase]/lim }\end{array}$ \\
\hline
\end{tabular}

\section{Collection, organization, and analysis of data}

After selection, information was extracted from the articles that made up the final corpus, based on an instrument structured on the general characteristics (year, journal, authors), methodological design, context, population and tested intervention, and outcomes on effects of skin protector spray and/or Calendula officinalis in prevention or treatment of radiodermatitis.

All studies were categorized according to the intervention applied and population characteristic in studies with marigold use in humans, studies with marigold use in mice and studies with skin protector use in humans. The authors adopted a level of statistical significance less than or equal to $5 \%$ for result significance analysis.

In human studies, two scales for skin assessment were used: the Common Terminology Criteria for Adverse Events of the National Cancer Institute (CTCAE), which follows an increasing order of acute skin toxicity: Grade 0, no reactions; Grade 1, mild; Grade 2, moderate; Grade 3, severe; Grade 4, life risk; Grade 5, death from adverse event ${ }^{(19)}$; and the Radiation Therapy Oncology Group of the European Organization for Research and Treatment of Cancer (RTOG/EORTC), which receives the following classification of skin assessment: Grade 0 , with no changes from the beginning; Grade 1, mild erythema, epilation and dry peeling, decreased sweating; Grade 2, moderate to bright erythema, uneven moist scaling, moderate edema; Grade 3 , confluent wet peeling in addition to skin folds, severe edema; Grade 4, ulceration, hemorrhage and necrosis; Grade 5, death ${ }^{(20)}$.

Study quality assessment was performed using the Joanna Briggs Institute (JBI) critical assessment tool for randomized clinical trials ${ }^{(21)}$ and the bias risk assessment tool in studies involving animals from the SYstematic Review Center for Laboratory Animal 
Experimentation (SYRCLE) ${ }^{(22)}$. These critical assessment tools help reviewers to assess whether there are systematic errors in conducting studies according to the design employed. Two authors performed this task independently. There was no intention to exclude documents from the sample based on assessment of studies.

A narrative synthesis of the findings and their main characteristics is presented. It was not possible to perform a quantitative synthesis (meta-analysis) of the findings comparing using skin protectors with Calendula officinalis for prevention and treatment of radiodermatitis, initial intention of the proposal.

\section{RESULTS}

Database searches resulted in 218 documents. After removing duplicates, 128 articles remained. One hundred and sixteen were excluded in the eligibility criteria stage, from reading all title and abstracts of documents. Seven were excluded, after applying the eligibility criteria from reading all texts in full. Therefore, only five studies made up the final sample. Study search and selection is represented graphically as a flowchart in Figure 1.

Chart 3 shows the main characteristics of the studies, and Charts 4 and 5 show the results of the critical appraisal process.

$A 1^{(15)}$, a split-cluster Randomized Clinical Trial ${ }^{(26)}$, compared the effectiveness of $3 \mathrm{M}^{\mathrm{m} m}$ Cavilon ${ }^{\mathrm{m}}$ No Sting Barrier Film and Mometasone Furoate Cream (Elomet ${ }^{\circ}$ ), a synthetic corticosteroid for radiodermatitis prevention in breast cancer patients undergoing radiation therapy and who have undergone mastectomy or breast conservative surgery. Thirty-nine study participants were randomly allocated to 3 groups: (1) $3 \mathrm{M}^{\mathrm{m}}$ Cavilon $^{\mathrm{m}}$ No Sting Barrier Film versus without treatment $(n=13)$; (2) Elomet versus without treatment $(n=9)$; (3) Elomet ${ }^{\circ}$ versus $3 \mathrm{M}^{\mathrm{m}}$ Cavilon $^{\mathrm{m}}$ Co $^{\mathrm{m}}$ No Sting Barrier Film $(n=17)$. The areas of application of the products assessed were divided from the perpendicular line in relation to the surgical scar; however, the authors did not inform which products were applied on the medial or lateral side. Assessment was made using the CTCAE scale, version 3.0. The only statistically significant result was Elomet', reaching 53.4 days until Grade 2 radiodermatitis occurrence in the group in which it was compared with $3 \mathrm{M}^{\mathrm{m}}$ Cavilon ${ }^{\mathrm{m}}$ 'No Sting Barrier Film, which reached 44.5 days.

$\mathrm{A} 2^{(23)}$, also a split-cluster Randomized Clinical Trial(26), compared the effectiveness of $3 \mathrm{M}^{\mathrm{m}}$ Cavilon ${ }^{\text {mm }}$ No Sting Barrier Film and Sorbolene cream, composed of water and oils with $10 \%$ glycerin, for prevention of wet flaking in mastectomized patients undergoing radiation therapy. Sixty-one participants were randomly allocated into two groups according to the region of treatment application (medial or lateral) according to the hemiclavicular line and according to the type of treatment (Cavilon ${ }^{\text {'m }}$ or Sorbolene): (1) application medial of $3 \mathrm{M}^{\mathrm{Tm}}$ Cavilon ${ }^{\mathrm{m}}$ No Sting Barrier Film and side of Sorbolene cream ( $n=31)$ and (2) lateral application of $3 \mathrm{M}^{\mathrm{Tm}}$ Cavilon ${ }^{\mathrm{Tm}}$ No Sting Barrier Film and medial of Sorbolene cream $(n=30)$. Assessment was performed by applying the RTOG scale weekly until the skin reactions to radiotherapy were resolved or up to 12 weeks, whichever was less. The intention to treat analysis showed 46 patients with an RTOG score $=2$ in the areas treated with Sorbolene, against 33 in the areas treated with $3 \mathrm{M}^{\mathrm{m}}$ Cavilon ${ }^{\mathrm{m}}$ "No Sting Barrier Film.

$A 3^{(24)}$ assessed the preventive effects of skin toxicity by ionizing radiation (IR) of two products in SKH-hr1 mice (species name of hairless mice): (1) Ching Wan Hung (CWH), a Chinese herbal ointment that is sold as a lotion for burns, and (2) Calendula officinalis extract. In this study, 40 mice were divided into four groups of 10 animals: (1) control (without IR); (2) 10 Gy of IR for four days; (3) IR + Calendula officinalis; and (4) IR $+\mathrm{CWH}$. Erythema outcome assessment was carried out from dermoscopy in four moments (days 8 , 10, 12 and 14) using a gradation of three levels: (1) without visible lesion; (2) moderate injury; (3) severe injury. CWH demonstrated better effectiveness for preventing erythema than Calendula officinalis in mice, keeping the skin in all assessments without visible lesion. Meanwhile, the group treated with Calendula officinalis had six severe lesions and four moderate lesions on the $10^{\text {th }}$ and, in the last assessment, eight without injury and two moderate injuries.

$\mathrm{A} 4^{(9)}$ compared the effectiveness of Calendula officinalis (Pommade au Calendula par Digestion, Boiron Ltda.) and Trolamine (Biafine, Genmedix Ltda.) in preventing acute radiodermatitis during adjuvant radiotherapy in patients with breast cancer. Two hundred and fifty-four participants were randomly allocated to two groups. In one group, patients were treated with Trolamine emulsion $(n=128)$, and in the other, they were treated with Calendula officinalis $(n=126)$. Skin toxicity outcome assessment was performed using the RTOG scale. 
Chart 3 - Characteristics of the studies included in the review

\begin{tabular}{|c|c|c|c|}
\hline $\begin{array}{c}\text { Article } \\
\text { identification } \\
\text { Year/Country }\end{array}$ & Outlining/number of participants & Interventions & Outcome \\
\hline $\begin{array}{l}\mathrm{A} 1^{(15)} \\
2015 \\
\text { Taiwan }\end{array}$ & $\begin{array}{l}\text { Randomized Clinical Trial } \\
39 \text { human beings with breast cancer } \\
\text { Skin assessment scale: CTCAE, version } 3.0\end{array}$ & $\begin{array}{l}\text { Intraindividual comparisons: } \\
\text { Cavilon }{ }^{\prime \prime \prime} \times \text { without treatment (13); } \\
\text { Elomet }^{\circ} \times \text { without treatment (9); } \\
\text { Elomet }^{\circ} \times \text { Cavilon"' }(17)\end{array}$ & $\begin{array}{l}\text { Days for radiodermatitis: } \text { Cavilon }^{m}=44.2 \times \text { without } \\
\text { treatment }=46.6(p=0.196) ; \text { Elomet }^{\circ}=52 \times \text { without } \\
\text { treatment }=43(p=0.092) \text {; Elomet }{ }^{\circ}=53.4 \times \text { Cavilon }^{m}=44.5 \\
(p=0.002) .\end{array}$ \\
\hline $\begin{array}{c}\mathrm{A} 2^{(23)} \\
2004 \\
\text { Australia }\end{array}$ & $\begin{array}{l}\text { Randomized Clinical Trial } \\
61 \text { human beings with breast cancer } \\
\text { Skin rating scale: RTOG acute skin score }\end{array}$ & $\begin{array}{l}\text { Intraindividual comparisons: } \\
\text { Cavilon"' } \times \text { Sorbolene cream (61) }\end{array}$ & $\begin{array}{l}\text { Skin reaction score }>2 \text { : Sorbolene }=46 \% x \\
\text { Cavilon }{ }^{m}=33 \%(p=0.096)\end{array}$ \\
\hline $\begin{array}{l}A 3^{(24)} \\
2014 \\
\text { USA }\end{array}$ & $\begin{array}{l}\text { Pre-Clinical Trial } \\
40 \text { mice } \\
\text { Skin rating scale: ------------- }\end{array}$ & $\begin{array}{l}\text { Control (10) x lonizing Radiation: } \\
10 \text { Gy/day for } 4 \text { days (10) } x \\
\text { lonizing Radiation }+ \text { Calendula } \\
\text { officinalis (10) } x \text { lonizing Radiation } \\
+ \text { CWH ointment (10) }\end{array}$ & $\begin{array}{l}\text { On the } 14^{\text {th }} \text { day, for erythema: Control= } 10 \text { without } \\
\text { injury; lonizing radiation }=7 \text { without injury, } 3 \text { moderate } \\
\text { injuries; lonizing Radiation }+ \text { Calendula officinalis }=8 \\
\text { without injury, } 2 \text { moderate injuries; lonizing Radiation } \\
+C W H=10 \text { without injury }(p=0.033)\end{array}$ \\
\hline $\begin{array}{l}\mathrm{A} 4^{(9)} \\
2004 \\
\text { France }\end{array}$ & $\begin{array}{l}\text { Randomized Clinical Trial } \\
254 \text { human beings with breast cancer } \\
\text { Skin rating scale: RTOG acute skin score }\end{array}$ & $\begin{array}{l}\text { Calendula officinalis (126) x } \\
\text { Trolamine (128) }\end{array}$ & $\begin{array}{l}\text { Overall skin toxicity }(p=<0.001) \text { : Calendula } \\
\text { officinalis - score } 0-1=74 \text {, score } 2-3=52 ; \text { Trolamine - } \\
\text { score } 0-1=47 \text {, score } 2-3=81\end{array}$ \\
\hline $\begin{array}{l}\text { A5 } \\
2015 \\
\text { Brazil }\end{array}$ & $\begin{array}{l}\text { Randomized Clinical Trial } \\
51 \text { human beings with head and neck cancer } \\
\text { Skin rating scale: RTOG acute skin score }\end{array}$ & EFA (27) x Calendula officinalis (24) & 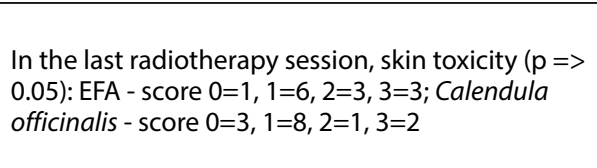 \\
\hline
\end{tabular}

Note: EFA - essential fatty acids; CTCAE - Common Terminology Criteria for Adverse Events; CWH - Ching Wan Hung; RTOG - Radiation Therapy Oncology Group; Gy - Gray, unit of measurement of electromagnetic ionizing radiation.

Chart 4 - Result of Joanna Briggs Institute's critical assessment tool application for Randomized Clinical Trials

\begin{tabular}{|c|c|c|c|c|c|c|c|c|c|c|c|c|c|}
\hline Article identification & 1 & 2 & 3 & 4 & 5 & 6 & 7 & 8 & 9 & 10 & 11 & 12 & 13 \\
\hline$A 1^{(15)}$ & $\mathrm{N}$ & $\mathrm{N}$ & $\mathrm{N}$ & $\mathrm{N}$ & $\mathrm{N}$ & $\mathrm{N}$ & $N$ & $Y$ & $\mathrm{Y}$ & $\mathrm{Y}$ & $\mathrm{N}$ & $\mathrm{Y}$ & $\mathrm{Y}$ \\
\hline$A 2^{(23)}$ & $U$ & $\mathrm{Y}$ & $\mathrm{Y}$ & $\mathrm{N}$ & $\mathrm{N}$ & $\mathrm{N}$ & $N$ & $\mathrm{~N}$ & $Y$ & $\mathrm{Y}$ & $\mathrm{N}$ & $\mathrm{Y}$ & $\mathrm{Y}$ \\
\hline $\mathrm{A} 4^{(9)}$ & $Y$ & $\mathrm{~N}$ & $\mathrm{~N}$ & $\mathrm{~N}$ & $\mathrm{~N}$ & $Y$ & $\mathrm{~N}$ & $\mathrm{~N}$ & $Y$ & $Y$ & $\mathrm{Y}$ & Y & $\mathrm{N} / \mathrm{A}$ \\
\hline $\mathrm{A} 5^{(25)}$ & $Y$ & $\mathrm{Y}$ & $Y$ & $Y$ & $Y$ & $Y$ & $\mathrm{Y}$ & $\mathrm{N}$ & $\mathrm{N}$ & $Y$ & $\mathrm{Y}$ & $Y$ & $\mathrm{~N} / \mathrm{A}$ \\
\hline
\end{tabular}

Note: $Y$-yes; $N$-no; U-unclear; $N / A-$ not applicable.

Chart 5 - Result of the SYstematic Review Center for Laboratory animal Experimentation bias risk tool application for animal intervention studies

\begin{tabular}{|l|c|c|c|c|c|c|c|c|c|c|}
\hline Article identification & $\mathbf{1}$ & $\mathbf{2}$ & $\mathbf{3}$ & $\mathbf{4}$ & $\mathbf{5}$ & $\mathbf{6}$ & $\mathbf{7}$ & $\mathbf{8}$ & $\mathbf{9}$ & $\mathbf{1 0}$ \\
\hline $\mathrm{A}^{(24)}$ & $\mathrm{N}$ & $\mathrm{U}$ & $\mathrm{U}$ & $\mathrm{U}$ & $\mathrm{U}$ & $\mathrm{N}$ & $\mathrm{U}$ & $\mathrm{Y}$ & $\mathrm{Y}$ & $\mathrm{Y}$ \\
\hline
\end{tabular}

Note: $Y$-yes; $N$-no; $U$ - unclear; $N / A$ - not applicable.

In the overall assessment, $59 \%$ of participants treated with Calendula officinalis were rated 0 or 1 against $37 \%$ of those treated with Trolamine; therefore, $41 \%$ of those treated with Calendula officinalis were assessed with 2 or 3 against $63 \%$ of those treated with Trolamine.

A5 ${ }^{(25)}$ compared the effectiveness of Calendula officinalis and essential fatty acids (EFA) for prevention and treatment of radiodermatitis in patients with head and neck cancer. Fifty-one participants were randomly allocated to the groups Calendula officinalis $(n=24)$ and EFA ( $n=27)$. Skin toxicity outcome assessment was performed using the RTOG scale in eight moments, on the $5^{\text {th }}, 10^{\text {th }}, 15^{\text {th }}, 20^{\text {th }}, 25^{\text {th }}, 30^{\text {th }}$, $35^{\text {th }}$ session and 30 days after the last radiotherapy session. In the last session, $7.69 \%$ of participants treated with EFA were classified as grade 0 against $21.43 \%$ of those treated with Calendula officinalis; $46.15 \%$ of the EFA group had Grade 1, against $57.14 \%$ of the Calendula officinalis group; $23.08 \%$ had Grade 2 in the EFA group, against
$7.14 \%$ in the Calendula officinalis group; and $23.08 \%$ had Grade 3 in the EFA group, against $14.29 \%$ in the Calendula officinalis group. In the assessment performed 30 days after treatment, the results remained favorable to the Calendula officinalis group in relation to the EFA group.

As for the quality of studies, the result of critical assessment tool application revealed weaknesses regarding internal validity, mainly related to selection, performance, and attrition biases.

\section{DISCUSSION}

A1, A2 and A4 contained selection biases, due to problems with true randomization and/or with participant allocation and performance confidentiality, due to non-blinding those who applied and those who received treatment and control. A1 and A2 still had detection bias, as there was no blinding of those who assessed the outcomes. Although A2 and A4 performed intention-to-treat analysis, the impacts of follow-up losses from participants who left the studies were not adequately analyzed. Therefore, they had friction biases, such as A5, which did not carry 
out an analysis concerning the intention to treat or follow-up loss impact. A3, on the other hand, presented little information regarding systematic errors in conducting the study.

The results presented show that there is an important lack of studies on the effectiveness of both skin protectors spray and Calendula officinalis for prevention and treatment of radiodermatitis. Among the identified results, Cavilon ${ }^{\mathrm{TM}}$ was more effective than Sorbolene and less effective than Elomet ${ }^{\circ}$ for prevention and treatment of radiodermatitis in the breast area.

This result can be compared with a scope review that mapped evidence on the effectiveness of a no sting barrier film spray, a skin protector that was developed as an alternative to petrolatum ointments and zinc oxide formulas. Six studies were included in the research, which investigated the action of this skin protector in relation to pressure ulcers or vascular ulcers in the legs, urinary or fecal incontinence and post-mastectomy irradiation. The main clinical outcomes assessed were: injury healing, exudates and erythema control; incidence of dermatitis associated with incontinence and skin reactions; pruritus intensity and skin reactions. Formulations of zinc oxide and petrolatum were the most common comparison interventions in research on chronic ulcers and incontinence. Sorbolene cream and topical corticosteroids were the most frequent comparisons in post-mastectomy irradiation situations ${ }^{(27)}$.

The research concluded that skin protectors can be used to protect the peripheral skin in patients with chronic injuries, with urinary or fecal incontinence and for women submitted to postmastectomy irradiation; however, it indicated the need for more robust experimental studies in all clinical fields ${ }^{(27)}$.

Another study assessed using film barrier in reducing the severity of radiodermatitis in patients with breast cancer and in relation to the perception of these patients regarding the results of its use. The study included 101 Danish patients, randomized based on Mepitel film application on the lateral or medial part of the breast, with the patients being their own control. The primary endpoint assessed was the patient's report of symptoms and experience, and the secondary endpoint was radiodermatitis assessment by the radiotherapy team ${ }^{(28)}$.

Patients reported a significantly lower level of pain, itching, stinging as well as edema and reduced sensitivity in the skin area covered by the film. Most patients preferred barrier film throughout the treatment area and Mepitel ${ }^{\circ}$ film as a standard treatment option. Patients treated after mastectomy had a lower severity of radiodermatitis at the end of radiotherapy with film barrier use compared to standard treatment ${ }^{(28)}$.

This positive result obtained with the Mepitel ${ }^{\circ}$ film is consistent with a systematic review that assessed the evidence on the effectiveness of semi-permeable dressings in preventing radiodermatitis in cancer patients. Efficacy was assessed based on objective skin reaction indicators and subjective symptoms of patients. Six randomized clinical trials were included. Three analyzed Mepitel ${ }^{\circ}$ film application in patients with breast cancer and head and neck cancer; one assessed Mepitel film application in patients with breast cancer; and two assessed silver nylon dressing use in patients with breast cancer and low gastrointestinal cancer. Analysis indicated that semi-permeable dressings were beneficial in controlling skin toxicity related to radiation therapy, but rigorous trials showing stronger evidence are needed ${ }^{(29)}$.
From the above, considering that the Oncology Nursing Society classifies skin protectors as not established efficacy, the present review shows that skin protectors are a promising alternative in prevention of radiodermatitis. However, there was a predominance of studies with patients with breast cancer and head and neck cancer. Therefore, it is important to develop new studies that assessed the effectiveness of skin protectors for prevention and treatment of radiodermatitis in cancer patients in other irradiated regions, in particular, regions with a higher risk of radiodermatitis, such as the anal and rectum canal.

Another result obtained in this review showed greater effectiveness of Calendula officinalis in relation to Trolamine and EFA. This is in line with the results of a systematic review with meta-analysis on Trolamine use, which concluded that Trolamine is not recommended as a standard alternative for prevention or treatment of radiodermatitis in patients with breast and head and neck cancer ${ }^{(30)}$.

$\mathrm{CWH}$ was more effective than Calendula officinalis. This data still requires further investigations to assess the effectiveness of $\mathrm{CWH}$ for prevention and treatment of radiodermatitis, since there is a lack of studies on its use. One of the researches recruited for this discussion assessed the effectiveness of the compound in the treatment of burns in mice ${ }^{(31)}$. Despite this, there is evidence about the anti-inflammatory action of two of its main active components, myrrh ${ }^{(32-34)}$, and sanguisorb $a^{(35-37)}$.

It is noteworthy that, based on the results obtained, the occurrence of radiodermatitis compromises patient safety, since the severity of this lesion, especially when there is extensive wet desquamation, in addition to causing interruption of treatment, is also related to the worst quality of life due to local hypersensitivity, pruritus, pain due to exposure of nerve endings and loss of protective barrier, with risk of infection ${ }^{(14,38)}$.

In this context, the role of nurses in managing skin toxicities from radiotherapy is essential. A systematic review carried out in Greece showed that $50 \%$ of the selected studies reported benefits to the patient with head and neck cancer undergoing radiation therapy after the application of nursing interventions. Nurses often led interventions aimed at quitting alcohol use and smoking cessation, reducing depressive symptoms, attention to information needs, improving adherence to radiotherapy, assessing trismus, with positive results in quality of life ${ }^{(39)}$.

Nurses, in nursing consultation, perform skin assessment using scales that classify the observed characteristics. Such scales provide important parameters for monitoring skin conditions during radiotherapy and direct the implementation of interventions and the education process for patients/family members.

Using products is part of the interventions planned by nurses for patients undergoing radiotherapy treatment in nursing consultation, and needs to be aligned with Evidence-Based Practice. These interventions must be holistic and multidisciplinary in nature, with identification of extrinsic and intrinsic risk factors for radiodermatitis; consideration of the efficacy and effectiveness of products, their impacts on quality of life; cost analysis, as well as in the face of individual patient variables and irradiated regions.

From this perspective, the results on screen point out that although interventions for radiodermatitis are targets of interest to the scientific community, robust studies are still needed to guide clinical practice, especially in prevention, aiming at achieving 
the success of interventions according to the specificities of the irradiated area.

\section{Contributions to nursing and health}

Studies on the effectiveness of products for prevention and treatment of radiodermatitis contribute to reducing their social and economic impacts, allowing less suffering to cancer patients and less time in idle by interrupting treatment. This time, the results presented contribute to guide the discussion of institutional protocols that support the clinical practice of professionals, especially nurses during nursing consultation.

\section{Study limitations}

There are limitations in the analysis of the effectiveness of skin protectors and Calendula officinalis for prevention and treatment of radiodermatitis proposed by this review, given the scarcity of studies, the low methodological quality and the small sample size.

\section{CONCLUSION}

The present review showed that the Cavilon ${ }^{\mathrm{m}}$ skin protector was more effective than Sorbolene and less effective than Elomet ${ }^{\circ}$ for preventing and treating radiodermatitis in the breast area. Moreover, Calendula officinalis was more effective than Trolamine and AGE in humans that had the breast and head and neck irradiated, respectively, and less effective than $\mathrm{CWH}$ in mice for prevention and treatment of radiodermatitis. Therefore, the data confirm the potential of Calendula officinalis in preventing radiodermatitis and point to promising results regarding using skin protectors spray, which require further testing. The studies were not conclusive, either due to systematic driving errors or results without statistical significance.

\section{ERRATUM}

Article"Effectiveness of skin protectors and calendula officinalis for prevention and treatment of radiodermatitis: an integrative review", with number of DOI: https://doi. org/10.1590/0034-7167-2019-0815, published in thejournal Revista Brasileira de Enfermagem, 73(Suppl 5):e20190815:

The word "spray" is included: In Resumo, in the 1st and 11th line, after the term "protetores cutâneos". In Abstract, in the 1st and 10th row, after the term "skin protectors". In Resumen, in the 1st and 11th line, after the term "protectores cutâneos".

In the body of the article, include the word "spray" after the term "skin protectors" in the lines: 97 (Introduction), 108 (Objective), 133 (Method), 144 (Method), 167 (Method), 315 (Discussion), 450 (Conclusion).

In paragraph 11, delete the term: (risk factors for radiodermatitis)

\section{REFERENCES}

1. Bray F, Ferlay J, Soerjomataram I, Siegel RL, Torre LA, Jemal A. Global cancer statistics 2018: GLOBOCAN estimates of incidence and mortality worldwide for 36 cancers in 185 countries. CA Cancer J Clin. 2018;68(6):394-424. doi: 10.3322/caac.21492

2. INCA. Estimativa 2018: incidência de câncer no Brasil [Internet]. Rio de Janeiro; 2017 [cited 2019 Oct 10]. Available from: http://www1.inca. gov.br/estimativa/2018/estimativa-2018.pdf

3. Ruysscher D, Niedermann G, Burnet NG, Siva S, Lee AWM, Hegi-Johnson F. Radiotherapy toxicity. Nat Rev Dis Prim. 2019;5(1):13. doi: 10.1038/s41572-019-0064-5

4. Citrin DE. Recent developments in radiotherapy. N Engl J Med. 2017;377(11):1065-75. doi: 10.1056/NEJMra1608986

5. Rosenthal A, Israilevich R, Moy R. Management of acute radiation dermatitis: A review of the literature and proposal for treatment algorithm. J Am Acad Dermatol. 2019;81(2):558-67. doi: 10.1016/j.jaad.2019.02.047

6. Fuzissaki MA, Paiva CE, Oliveira MA, Lajolo Canto PP, Paiva Maia YC. The impact of radiodermatitis on breast cancer patients' quality of life during radiotherapy: a prospective cohort study. J Pain Symptom Manage. 2019;58(1):92-9. doi: 10.1016/j.jpainsymman.2019.03.017

7. Call JA, Prendergast BM, Jensen LG, Ord CB, Goodman KA, Jacob R, et al. Intensity-modulated radiation therapy for anal cancer: results from a multi-institutional retrospective cohort study. Am J Clin Oncol. 2016;39(1):8-12. doi: 10.1097/COC.0000000000000009

8. Santa Cruz O, Tsoutsou P, Castella C, Khanfir K, Anchisi S, Bouayed S, et al. Locoregional control and toxicity in head and neck carcinoma patients following helical tomotherapy-delivered intensity-modulated radiation therapy compared with 3D-CRT Data. Oncology. 2018;95(2):1-8. doi: 10.1159/000489217

9. Pommier P, Gomez F, Sunyach MP, D'Hombres A, Carrie C, Montbarbon X. Phase III randomized trial of calendula officinalis compared with trolamine for the prevention of acute dermatitis during irradiation for breast cancer. J Clin Oncol. 2004;22(8):1447-53. doi: 10.1200/ JCO.2004.07.063 
10. Murphy CT, Galloway TJ, Handorf EA, Egleston BL, Wang LS, Mehra R, et al. Survival impact of increasing time to treatment tnitiation for patients with head and neck cancer in the United States. J Clin Oncol. 2016;34(2):169-78. doi: 10.1200/JCO.2015.61.5906

11. Bese NS, Hendry J, Jeremic B. Effects of prolongation of overall treatment time due to unplanned interruptions during radiotherapy of different tumor sites and practical methods for compensation. Int J Radiat Oncol Biol Phys. 2007[cited 2019 Oct 10];68(3):654-61. Available from: https://www.redjournal.org/article/S0360-3016(07)00504-4/fulltext

12. Cruceriu D, Balacescu O, Rakosy E. Calendula officinalis: potential roles in cancer treatment and palliative care. Integr Cancer Ther. 2018;17(4):1068-78. doi: 10.1177/1534735418803766

13. Oncology Nursing Society Radiodermatitis (Radiation Skin Reactions): Improving symptom management in cancer care through evidence based practice [Internet]. Pittisburgh, PA: ONS; c2019 [cited 2019 Jun 17]. [about 2 screens]. Available from: https://www.ons.org/pep/radiodermatitis

14. Wan BA, Chan S, Herst P, Yee C, Popovic M, Lee J, et al. Mepitel Film and Mepilex Lite for the prophylaxis and treatment of skin toxicities from breast radiation. Breast. 2019;46:87-9. doi: 10.1016/j.breast.2019.05.012

15. Shaw S-Z, Nien H-H, Wu C-J, Lui LT, Su J-F, Lang C-H. 3M Cavilon No-Sting Barrier Film or topical corticosteroid (mometasone furoate) for protection against radiation dermatitis: a clinical trial. J Formos Med Assoc. 2015;114(5):407-14. doi: 10.1016/j.jfma.2013.04.003

16. Pignol JP, Vu TT, Mitera G, Bosnic S, Verkooijen HM, Truong P. Prospective evaluation of severe skin toxicity and pain during postmastectomy radiation therapy. Int J Radiat Oncol Biol Phys. 2015;91(1):157-64. doi: 10.1016/j.jirobp.2014.09.022

17. Mendes KDS, Silveira RC de CP, Galvão CM. Integrative literature review: a research method to incorporate evidence in health care and nursing. Texto Contexto Enferm. 2008;17(4):758-64. doi: 10.1590/S0104-07072008000400018

18. Shlonsky A, Gibbs L. Will the real evidence-based practice please stand up? tea the process of evidence-based practice to the helping professions. Br Treat Cris Interv. 2004;4(2):137-53. doi:10.1093/brief-treatment/mhh011

19. US Department of Health and Human Services. Common Terminology Criteria for adverse events (CTCAE) version 5.0 [Internet]. 2017 [cited $2020 \mathrm{Dec} 19]$. Available from https://ctep.cancer.gov/protocoldevelopment/eletronic_applications/docs/ctcae_v5_quick_reference_8.5x11.pdf

20. Cox JD, Stetz J, Pajak TF. Toxicity criteria of the Radiation Therapy Oncology Group (RTOG) and the European Organization for Research and Treatment of Cancer (EORTC). Int J Radiat Oncol Biol Phys. 1995;31(5):1341-6.

21. The Joanna Briggs Institute. Checklist for Randomized Controlled Trials [Internet]. Adelaide; 2017[cited 2020 Dec 19]. Available from: https:// joannabriggs.org/sites/default/files/2019-05/JBI_RCTs_Appraisal_tool2017_0.pdf

22. Hooijmans CR, Rovers MM, Vries RB, Leenaars M, Ritskes-Hoitinga M, Langendam MW. SYRCLE's risk of bias tool for animal studies. BMC Med Res Methodol. 2014;14(1):43. doi: 10.1186/1471-2288-14-43

23. Graham P, Browne L, Capp A, Fox C, Graham J, Hollis J, et al. Randomized, paired comparison of No-Sting Barrier Film versus sorbolene cream (10\% glycerine) skin care during postmastectomy irradiation. Int J Radiat Oncol. 2004;58(1): 241-6. doi: 10.1016/S0360-3016(03)01431-7

24. Hu JJ, Cui T, Rodriguez-Gil JL, Allen GO, Li J, Takita C, et al. Complementary and alternative medicine in reducing radiation-induced skin toxicity. Radiat Environ Biophys. 2014;53(3):621-6. doi: 10.1007/s00411-014-0540-y

25. Schneider F, Danski MTR, Vayego SA. Usage of Calendula officinalis in the prevention and treatment of radiodermatitis: a randomized double-blind controlled clinical trial. Rev Esc Enferm USP. 2015;49(2):221-8. doi: 10.1590/S0080-623420150000200006

26. Shoukri MM, Colak D, Donner A. Likelihood inference on the relative risk in split-cluster designs. Clin Trials J Soc Clin Trials. 2011;8(1):37-47. doi: $10.1177 / 1740774510392254$

27. Micheli C, Palese A, Canzan F, Ambrosi E. Sting barrier film to protect skin in adult patients: findings from a scoping review with implications for evidence-based practice. Worldviews Evid Based Nurs. 2017;14(5):403-11. doi:10.1111/wvn.12232

28. Moller PK, Olling K, Berg M, Habaek I, Haislund B, Iversen AM. Breast cancer patients report reduced sensitivity and pain using a barrier film during radiotherapy - A Danish intra-patient randomized multicentre study. Tech Innov Patient Support Radiat Oncol. 2018;7:20-25. doi:10.1016/j.tipsro.2018.05.004

29. Fernandez-Castro M, Martín-Gil B, Peña-García I, López-Vallecillo M, García-Puig ME. Effectiveness of semi-permeable dressings to treat radiation-induced skin reactions: a systematic review. Eur J Cancer Care (Engl). 2017;26(6):10.1111/ecc.12685. doi: 10.1111/ecc.12685

30. Menêses AG, Reis PED, Guerra ENS, Canto GDL, Ferreira EB. Use of trolamine to prevent and treat acute radiation dermatitis: a systematic review and meta-analysis. Rev Latino-Am Enfermagem. 2018;26(e2929). doi: 10.1590/1518-8345.2035.2929

31. Feng $X$, Cheng G, Chen S, Yang H, Huang W. Evaluation of the burn healing properties of oil extraction from housefly larva in mice. J Ethnopharmacol. 2010;130(3):586-92. doi: 10.1016/j.jep.2010.05.044

32. Morikawa T, Matsuda H, Yoshikawa M. A Review of anti-inflammatory terpenoids from the incense gum resins frankincense and myrrh. J Oleo Sci. 2017;66(8):805-14. doi: 10.5650/jos.ess16149

33. Mahmoud AM, Zaki AR, Hassan ME, Mostafa-Hedeab G. Commiphora molmol resin attenuates diethylnitrosamine/phenobarbital-induced hepatocarcinogenesis by modulating oxidative stress, inflammation, angiogenesis and Nrf2/ARE/HO-1 signaling. Chem Biol Interact. 2017;270:41-50. doi: 10.1016/j.cbi.2017.04.012

34. Han X, Beaumont C, Stevens N. Chemical composition analysis and in vitro biological activities of ten essential oils in human skin cells. Biochim Open. 2017;5:1-7. doi: 10.1016/j.biopen.2017.04.001 
35. Jang E, Inn K-S, Jang YP, Lee K-T, Lee J-H. Phytotherapeutic activities of sanguisorba officinalis and its chemical constituents: a review. Am J Chin Med. 2018;46(02):299-318. doi: 10.1142/S0192415X18500155

36. Na E-J, Kim D-J, Kim J-H, Kim G-R. Recent trends in anti-obesity and anti-inflammatory studies in modern health care. Technol Heal Care. 2019;1-12. doi: 10.3233/THC-191736

37. Su XD, Guo RH, Li HX, Ma JY, Kim YR, Kim YH, et al. Anti-allergic inflammatory components from Sanguisorba officinalis L. Bioorg Med Chem Lett. 2018;28(12):2210-6. doi: 10.1016/j.bmcl.2018.04.033

38. Borghini A, Vecoli C, Mercuri A, Petruzzelli MF, D'errico MP, Portaluri M, et al. Genetic risk score and acute skin toxicity after breast radiation therapy. Cancer Biotherapy Radiopharm. 2014;29(7):267-72. doi: 10.1089/cbr.2014.1620

39. Stylianou C, Kafasi A, Papageorgou DK. Nurse led interventions for patients with head and neck cancer. Nosileftiki [Internet]. 2017 [cited 2019 Mar 18];56(2):97-106. Available from: https://www.researchgate.net/ publication/325582126_Nurse_led_interventions_for_patients_with_head_and_neck_cancer 